\title{
Calorific and carbon values of marine and freshwater Protozoa
}

\author{
B. J. Finlay ${ }^{1}$ \& G. Uhlig $^{2}$ \\ Freshwater Biological Association, The Ferry House; Ambleside, Cumbria LA22 OLP, \\ $U . K$. \\ 2 Biologische Anstalt Helgoland (Meeresstation); D-2192 Helgoland, \\ Federal Republic of Germany
}

\begin{abstract}
Calorific and carbon values were determined for a variety of marine and freshwater Protozoa (Noctiluca miliaris, Euplotes sp., Eufolliculina sp. respectively Tetrahymena pyriformis, Paramecium caudatum), their food sources (Bacteria, Dunaliella primolecta, Ceratium hirundinella), and for Protozoa-dominated plankton samples. Most calorific values lie close to the centre of the range covering organisms in general. Low values in some marine samples probably resulted from the retention of bound water in the dried material. When all results were combined with data selected from the literature, the dependence of calorific value on carbon content was highly significant. This relationship is probably also adequately described by an energy-carbon regression through the variety of organic compounds commonly found in organisms. Calorific value expressed per unit carbon is shown to vary little in Protozoa (mean conversion factor $46 \mathrm{~J}[\mathrm{mg} \mathrm{C}]^{-1}$ ) or throughout the range of biological materials considered in this study $\left(45 \mathrm{~J}[\mathrm{mg} \mathrm{C}]^{-1}\right)$.
\end{abstract}

\section{INTRODUCTION}

Protozoa probably make an important contribution to energy flow in a variety of ecosystems (Fenchel, 1967; Curds, 1973; Berk et al, 1977; Finlay 1978; Porter et al., 1979). Nevertheless, data facilitating the conversion of units of biomass (e, g. dry weight, carbon) to units of energy (heats of combustion, expressed as Joules or calories) are few and scattered in the literature. This is probably a result of the obvious practical problems associated with obtaining relatively large amounts of pure, dry Protozoa. To the authors' knowledge there are no published calorific values for marine heterotrophic Protozoa and no studies providing complimentary figures for carbon content. The latter might be used to predict calorific values in a way similar to those already shown for aquatic invertebrates (Ostapenya \& Sergeev, in Winberg \& Duncan, 1971; Salonen et al., 1976).

This study is concerned with providing data for the calorific value, carbon content and nitrogen content of a variety of marine and freshwater Protozoa. The usefulness of carbon content in predicting calorific value is described. Factors employed in energycarbon conversions are compared with other published data for marine phytoplankton and freshwater aquatic invertebrates. 


\section{MATERIAL AND METHODS}

\section{Cultivation and preparation of marine samples}

Marine bacteria. The unidentified bacterium used as a food source in this study was isolated by Rieper (1981) from intertidal sediments at List/Sylt. It was cultured in peptone yeast extract medium (2216 E, according to Oppenheimer \& ZoBell, 1952) and harvested by continuous passage-centrifugation after 5 days growth at $24^{\circ} \mathrm{C}$ in the dark.

Dunaliella primolecta. Originally obtained as a clonal culture from the Marine Biological Association, Plymouth, U. K., Dunaliella primolecta is mass cultured at the Marine Station Helgoland in aerated 45-litre plastic bags with pasteurized f/2medium (McLachlan, 1973). The alyae (late log-phase) were concentrated by continuous passage-centrifugation up to $10^{6}$ cells $\mathrm{cm}^{-3}$.

Noctiluca miliaris. Isolated from Helgoland waters, this dinoflagellate has been cultured for many years at the Marine Station Helgoland (Uhlig, 1972). Daily feeding with concentrated Dunaliella primolecta produces population densities of more than $10^{5}$ cells $\mathrm{cm}^{-3}$ (Uhlig, 1980).

In well-fed cultures, Noctiluca is distributed over the whole water column and the cells contain remarkable, often "sausage-like" food vacuoles (Fig. 1a). In starved cultures the seawater medium was changed without adding food for at lcast 24 hours.
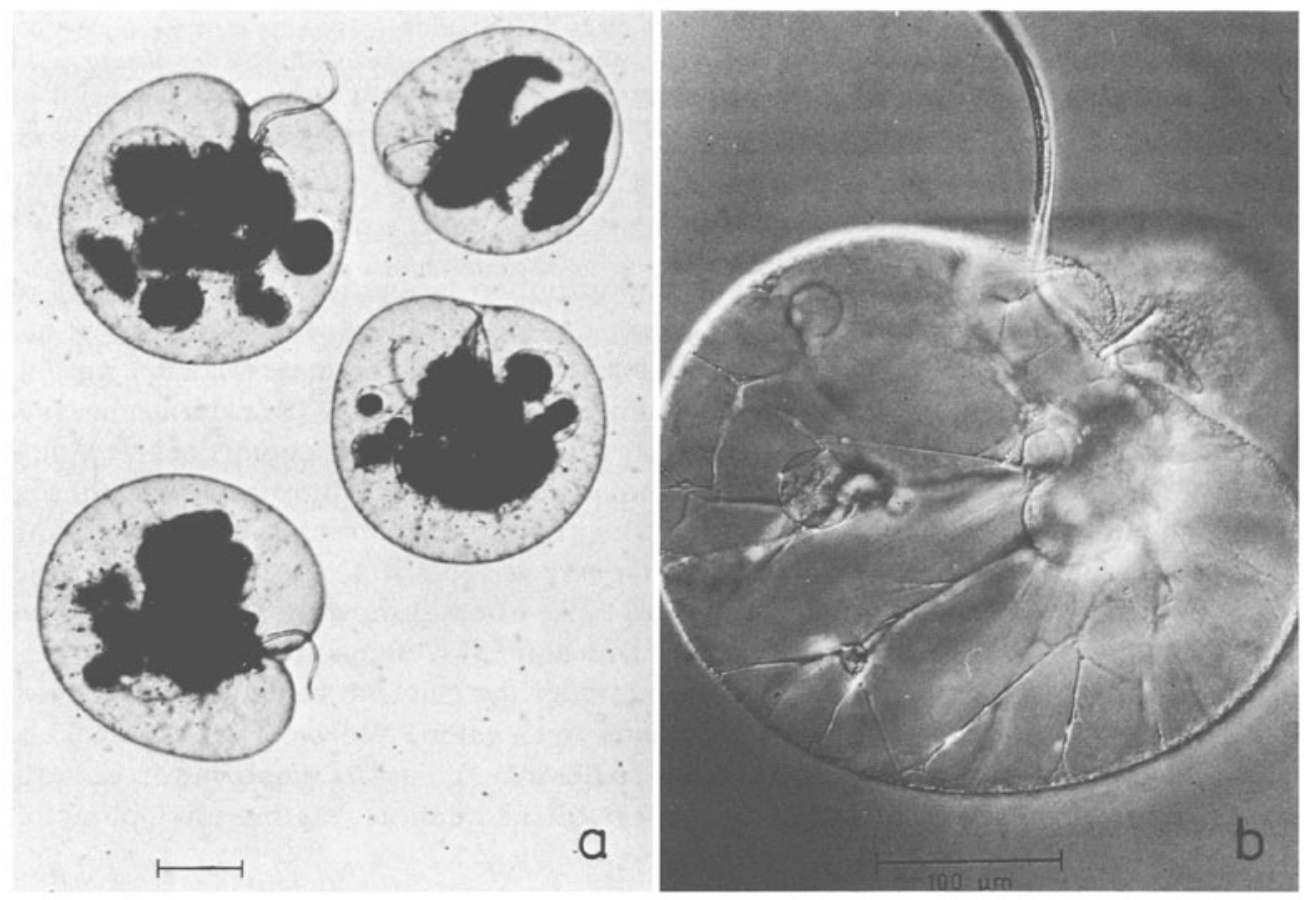

Fig. 1. Noctiluca miliaris. (a) Filled with food vacuoles of Dunaliella primolecta (photo: Sahlingl, (b) a single specimen from a starving culture. Scales: 100 um 
Starving cells (mean number of food vacuoles per cell $=0.38$ ) are more or less transparent (Fig. 1b).

The Noctiluca-dominated plankton sample was collected in July 1980 using a plankton net close to the surface. The samples were washed four times within a separating funnel to produce an almost uncontaminated mass of Noctiluca cells.

Euplotes $\mathrm{sp}$. This hypotrichous ciliate was isolated from a fish tank at Helgoland. In wide plexiglass dishes mass cultures $\left(>2 \times 10^{3} \mathrm{cells}^{-3}\right)$ were easily achieved by daily feeding with bacteria and/or Dunaliella primolecta, concentrated by centrifugation. The cells were washed and harvested on a $20 \mu \mathrm{m}$ nylon sieve.

Eufolliculina sp. Several species of the benthic, case-building folliculinids have been cultured at Helgoland for many years (Uhlig, 1965). Eufolliculina sp. is available in dense clonal mass cultures, fed with concentrated bacteria and/or Dunaliella primolecta. For the present study the densely settled cell accummulations in the culture dishes were carefully scraped off with a razor blade and harvested on a $40 \mu \mathrm{m}$ nylon sieve. All data on Eufolliculina presented in this study refer to a mixture of both cells and their chitinous ampullae.

Elimination of seawater in marine culture samples. For accurate dry weight determination contaminating salts in the culture media were eliminated by fast but gentle washing of the cell concentrates in a small volume of distilled water.

Microscopic examination confirmed that this procedure did not rupture the cells. Marine bacteria and Dunaliella primolecta were concentrated by centrifugation and washed by re-suspension in distilled water. Noctiluca, Euplotes and Eufolliculina were collected on nylon sieves $(80,20$ and $40 \mu \mathrm{m}$ respectively). Using distilled water and filter paper the cell concentrates retained on the sieves were washed and drained three times. The samples were then scraped or washed off the filters and oven-dried for $20 \mathrm{~h}$ at $70^{\circ} \mathrm{C}$. The plankton sample of Noctiluca was treated in the same way, then shock-frozen on $\mathrm{CO}_{2}$-ice and freeze dried.

\section{Cultivation and preparation of freshwater samples}

Heterotrophic Protozoa. All freshwater Protozoa were grown in 41 conical flasks at $20^{\circ} \pm 1^{\circ}$ in continuous dark. Tetrahymena pyriformis (strain 1630/1 W, Claff 1939) was obtained from the Culture Centre of Algae and Protozoa (Cambridge, U. K.). Axenically-grown Protozoa were cultured in proteose peptone $(2 \% \mathrm{w} / \mathrm{v})$ and yeast extract $(0.25 \% \mathrm{w} / \mathrm{v})$ medium and harvested by centrifugation after 7 days growth. The same species was also fed on bacteria. Cells were washed and transferred to filtered (GF/C) cerophyll $(0.15 \% \mathrm{w} / \mathrm{v})$ containing a growing, mixed culture of bacteria (see Bacteria below). They were harvested by collection on a $10 \mu \mathrm{m}$ sieve followed by centrifugation. Paramecium caudatum was isolated from detritus drifts bordering Lake Windermere (Cumbria, U. K.). It was grown in $0.15 \%$ cerophyll and fed on the bacterial flora accompanying the isolation. After 10 days growth it was harvested by collection on a $20 \mu \mathrm{m}$ sieve followed by centrifugation.

Freshwater bacteria. The bacterial flora accompanying the Paramecium isolate was grown in $0.25 \%$ cerophyll and harvested by centrifugation after 5 days growth at $20^{\circ}$ in the dark. 
Ceratium hirundinella. C. hirundinella, clone 258 from the Freshwater Biological Association culture collection, was grown using the method described by Heaney \& Furnass (1980). After approximately 14 days growth, cells were collected on a $20 \mu \mathrm{m}$ sieve, then concentrated by slow speed centrifugation.

Freshwater plankton samples. These were obtained from a small, shallow, highly productive pond (see Goulder, 1971 for description). Samples were collected with a phytoplankton net ( $\sim 50 \mu \mathrm{m}$ mesh) in July 1980. Plankton A samples were composed mainly of large ciliates (Loxodes, Frontonia, Spirostomum) and small dinoflagellates. Plankton B samples were composed mainly of rotifers in the genera Keratella and Polyarthra.

\section{Preparation of samples}

With the exception of the Noctiluca-plankton sample, which was freeze-dried, all samples were oven-dried for $16-20 \mathrm{~h}$ at $70^{\circ} \mathrm{C}$ then stored over $\mathrm{P}_{2} \mathrm{O}_{5}$ in a dessicator until required. Samples were then homogenised in a mortar and pressed into pellets (weight range $2-20 \mathrm{mg}$ ). These were placed on platinum pans and stored over silica gel before and after being weighed. Benzoic acid was used to aid combustion in samples with a high ash content. In such samples it accounted for approximately $50 \%$ of the pellet dry weight.

\section{Bomb calorimetry}

All calorific values were obtained using a Phillipson microbomb calorimeter. Corrections for acid production and heat release from the fuse wire were assumed to be unimportant and were ignored (Craig et al., 1978). The number of replicates was determined by the amount of material available and the consistency of the results obtained.

\section{Determination of ash weight}

The ash weight was calculated by (a) drying and ashing $\left(500^{\circ}\right.$ for $\left.16-20 \mathrm{~h}\right)$ the residue from bombed samples, or (b) ashing (as above) separate samples. There were always at least three replicates of the latter. Results obtained using these two methods often differed greatly, those obtained by the first method always being lower. Paine's (1971) suggestions were adopted and only values obtained by method (b) were used.

\section{Carbon and nitrogen}

Sub-samples of the material prepared for bomb calorimetry were analysed for carbon and nitrogen. Most data were obtained using the Carlo Erba automatic CHNAnalyser at the Marine Biological Association, Plymouth, U. K. A few samples were analysed with a Perkin Elmer CHN-Analyser. We assumed that carbonate carbon was insignificant (see Curl, 1962) in the samples analysed and that "\% carbon" can be considered equivalent to "\% organic carbon". 


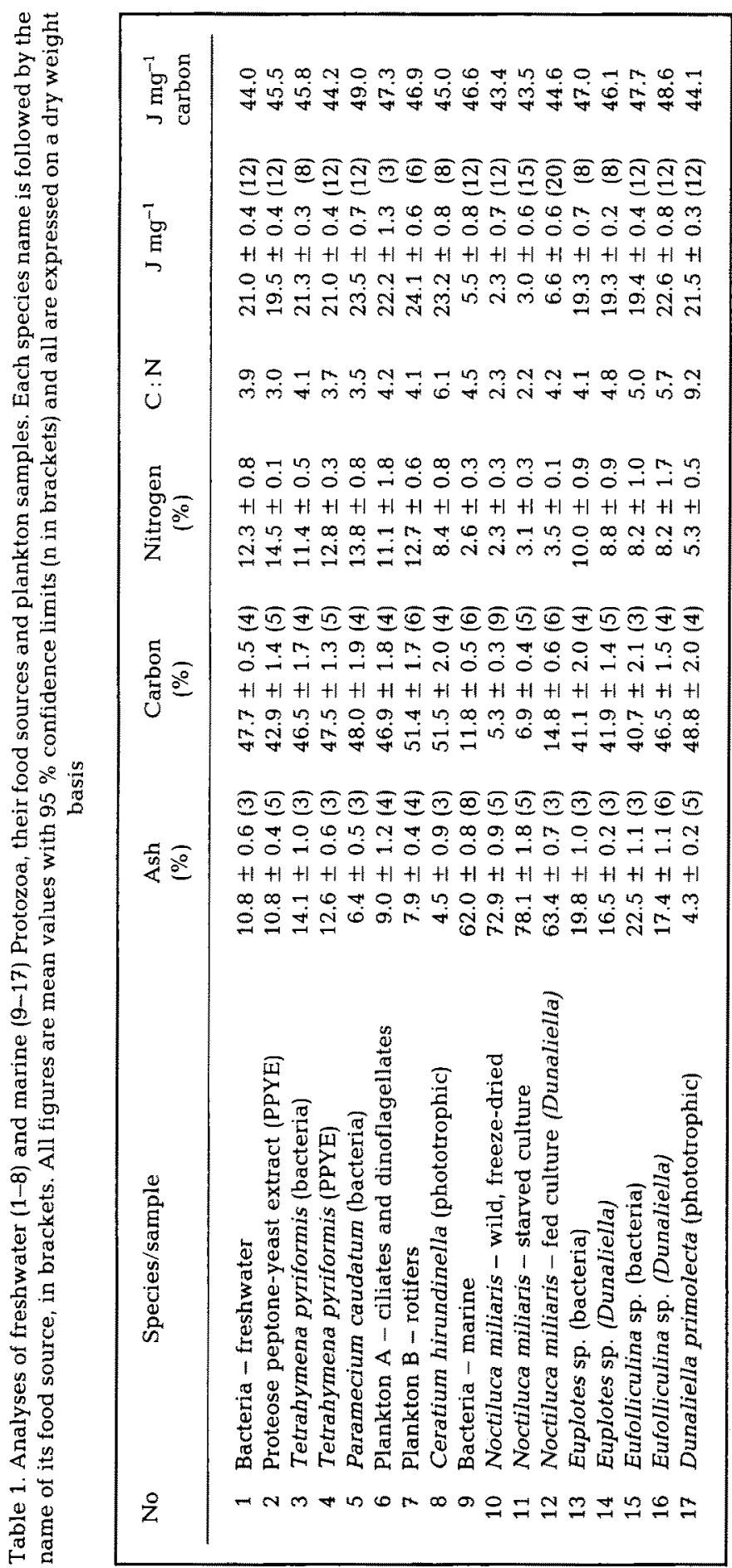




\section{RESULTS AND DISCUSSION}

The calorific and carbon values of all samples are presented in Table 1. It is assumed that the principal excretory product of Protozoa is ammonia (Kitching, 1967) and that a nitrogen correction of $-24.7 \mathrm{~J}(\mathrm{mg} \mathrm{N})^{-1}$ (Kersting, 1973) is appropriate. This correction significantly reduces the calorific value of samples with a high nitrogen content. For example, the corrected and uncorrected values for Paramecium are 20.1 and $23.5 \mathrm{~J} \mathrm{mg}^{-1}$ dry weight (DW) respectively.

With the possible exception of Eufolliculina, the calorific value did not change significantly with a change in the nature of the food source. However, the presence of ingested algae in Noctiluca did significantly increase its calorific value and C:N ratio. The intracellular volume of salty water displaced by ingesta was presumably also the reason for the lower ash content of cells that had been fed in the period prior to analysis. The higher ash content of the bacterial food source is also reflected in the higher ash content of bacteria-fed Protozoa.

With the exception of the four samples with the lowest carbon values (9-12) there was little variation between the calorific values of laboratory-grown Protozoa, their food sources, and samples from the wild. The data for freshwater Protozoa lie close to values

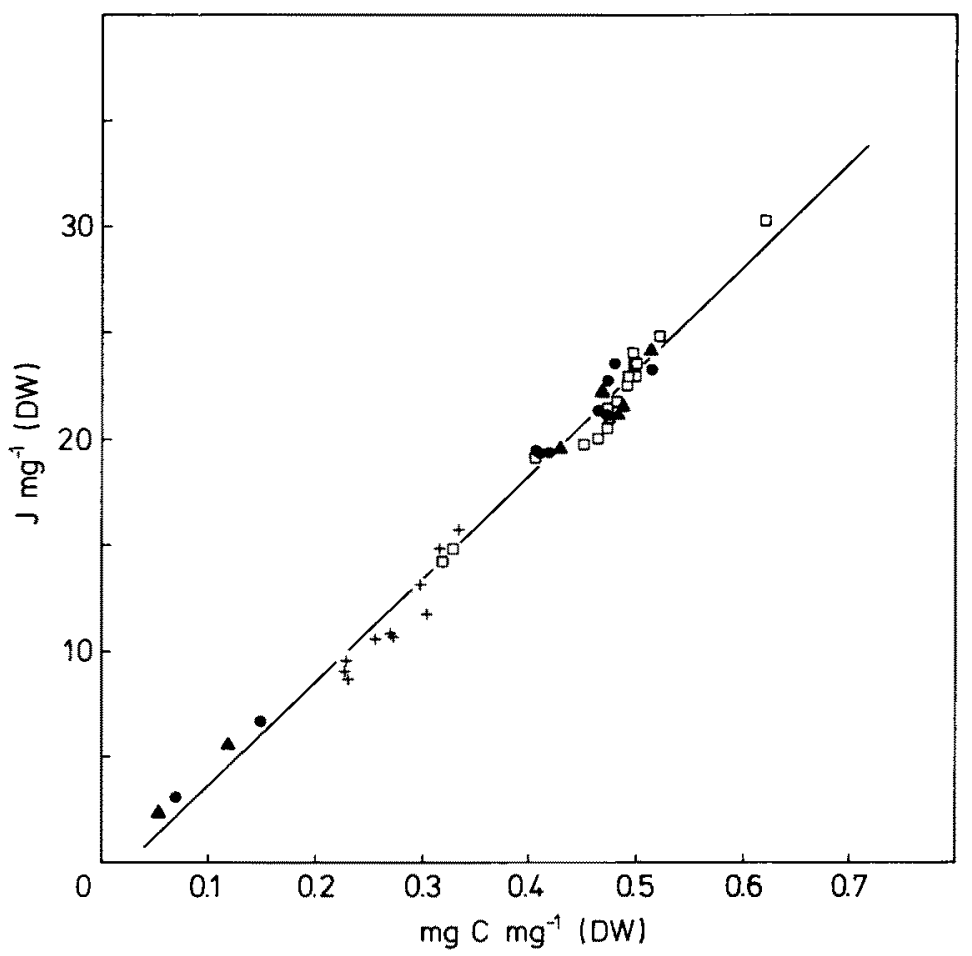

Fig. 2. Dependence of calorific value on carbon content on a dry weight basis (DW). Data are included from this study. Laboratory-grown protozoa: $\bullet$, food sources and plankton samples: $\boldsymbol{\Lambda}$, data of Salonen et al. (1976): $\square$, and re-calculated data of Platt \& Irwin (1973): +. y = $-1.289+48.57 x$ $\left(r^{2}=0.983\right)$ 


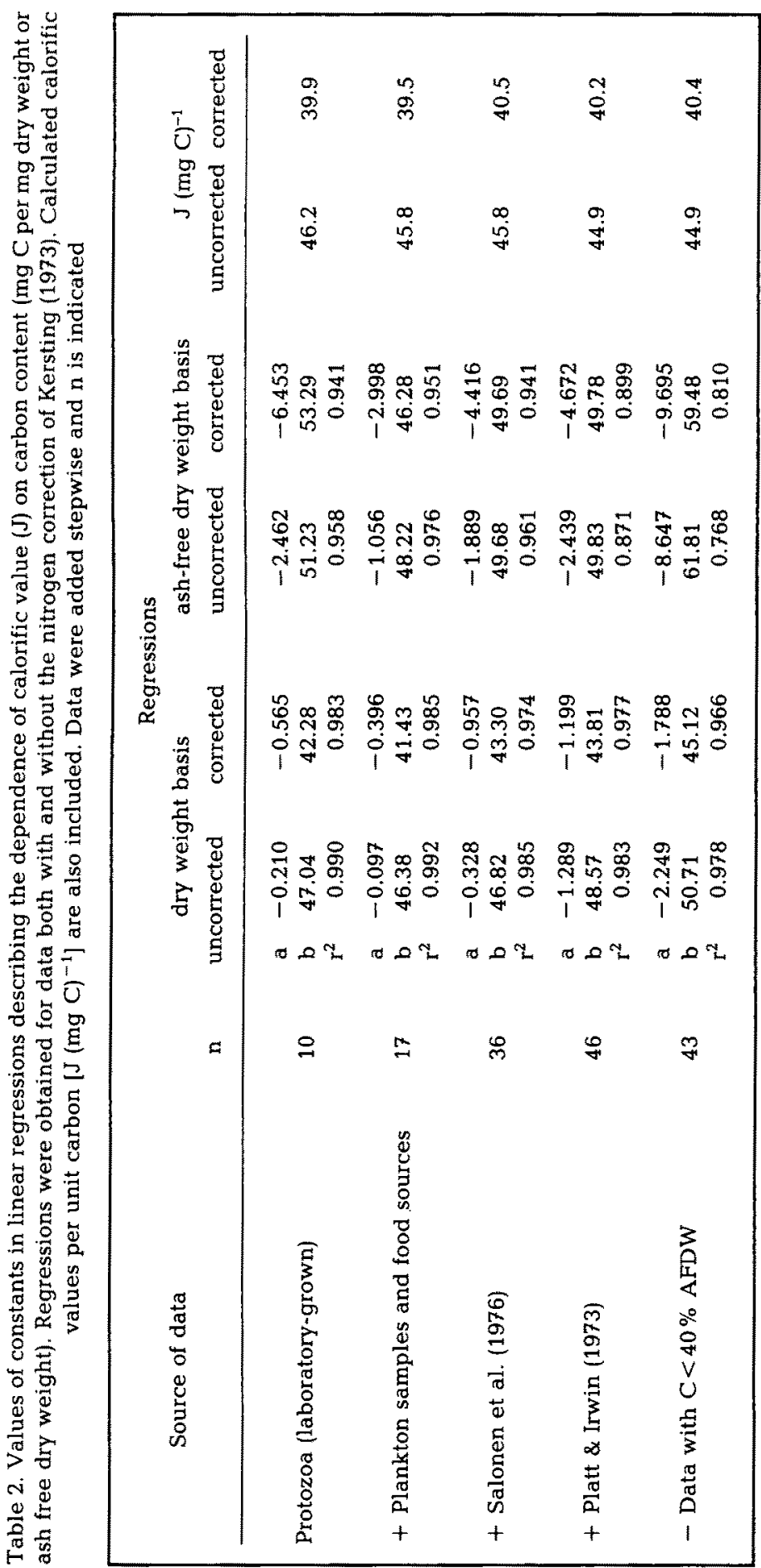


in the literature for various species (Slobodkin \& Richman, 1961; Laybourn \& Stewart, 1975; Rogerson, 1971; Kopylov, 1979) and towards the centre of the frequency distribution for all organisms prepared by Cummins \& Wuycheck (1971). The value for freshwater bacteria is close to the mean figure for bacteria obtained by Prochazcha et al. (1973).

Two other sets of data were selected for comparison with the figures presented here. They are (a) the marine phytoplankton data from Platt \& Irwin (1973) with carbon and nitrogen values re-calculated from the published macromolecular composition (see Salonen et al., 1976) and (b) the freshwater invertebrate data of Salonen et al. (1976). All of these data have been combined in Figure 2 which shows the predicted dependence of calorific value on carbon content. Most of the protozoan data form a cluster with the other invertebrate data indicating similarities in chemical composition. The carbon values for the three Noctiluca samples and the marine bacteria are all very low and, at least in one case (Noctiluca-plankton), impossibly low. Most organic compounds have a carbon content of over $40 \%$ and only in exceptional cases does carbon represent as little as $30 \%$ of the weight (e. g. cystine). Similarly, only organisms with a very unusual chemical composition could have a carbon content (as \% ash-free dry weight) lower than $40 \%$. Accordingly, samples with carbon values less than $40 \%$ have been removed from the relationship describing the dependence of calorific value on carbon content (Fig. 3 ). Regressions have been produced describing the relationship between calorific and carbon values, both on a dry weight and on an ash-free dry weight basis, with and without a nitrogen correction (Table 2). The data for Protozoa, their food sources, freshwater invertebrates and marine phytoplankton were incorporated in a stepwise manner. It is apparent that the regression statistics and values for $\mathrm{J}(\mathrm{mg} \mathrm{C})^{-1}$ are relatively insensitive to changes in the amount and type of data incorporated, indicating fundamental similarities in the organic composition of the diversity of samples analysed.

The underlying basis for the form of these relationships is the dependence of calorific value on carbon content in the organic compounds of which these organisms are composed. It is evident from Figure 3 that the relationship between calorific value and carbon in organisms is similar to that in the constituent organic compounds. Also included is an indication of the close relationship between calorific values obtained from proximate analysis and those obtained directly. Probable extreme ranges of the three principal macromolecular types in the ciliate Tetrahymena were used to generate the maximum probable range of calorific values in this organism. The composition of these hypothetical low - and high - energy organisms is described in Table 3.

The most likely reason for some samples yielding such low carbon and energy contents is the retention of bound water during drying. The higher salt content of the marine samples (especially in the case of Noctiluca from the relatively high volume of cell sap) and the probable incomplete dehydration of crystalline hydrates at $70^{\circ}$ (Mitchell \& Smith, 1977) implies that there is probably a bound water component included in some recorded weights. The size of this component can be estimated roughly by subtracting the sum of the organic and ash weights from the measured dry weights. The difference will be the weight of bound water. The probable range of organic weights in a sample was obtained by assuming that carbon accounted for between $45 \%$ and $65 \%$ of the organic weight. The calculated bound water component for each sample then lies within the ranges described in Table 4 . In most samples it is unlikely that carbon accounts for as little as $45 \%$ of the organic weight. One result of this assumption 


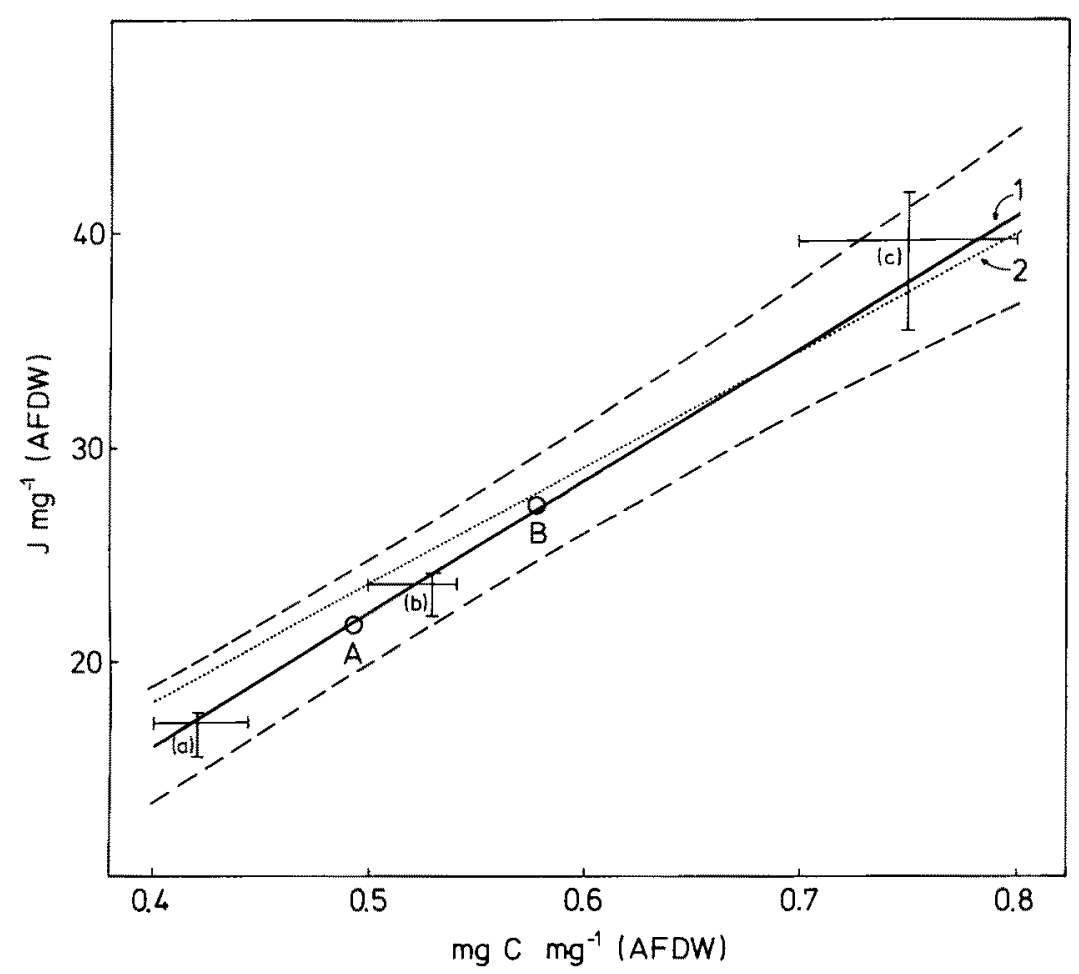

Fig. 3. Dependence of calorific value on carbon content, on an ash free dry weight (AFDW) basis. Regression (1) is calculated from all data in Fig. 2 with $>40 \%$ carbon (AFDW), $y=-8.647+$ $61.81 \times\left(n=43 ; r^{2}=0,768\right)$ and $95 \%$ prediction belts are drawn. Regression (2) is calculated through 21 organic compounds ( 3 sugars and glycogen, the 12 amino acids listed by Elliot \& Davison, 1975, and 5 lipids). $y=-3.331+54.00 x\left(r^{2}=0.889\right)$. Further data have been superimposed for comparative purposes. Points A and B represent the hypothetical values for Tetrahymena pyriformis in Table 3, and ranges (a), (b) and (c) refer to carbohydrates, proteins and lipids respectively. The ranges were obtained from Winberg (1971) apart from the lower lipid calorific value which is from Craig et al. (1978). Each pair of ranges meet at values representative of the compounds concerned

is that the calculated sum of the organic and ash weights can be in excess of the dry weight leaving no weight unaccounted for that can be ascribed to "bound water". This excess is described in Table 4 as a negative bound water component.

These ranges are broad but bound water is probably insignificant in most samples, especially those of freshwater origin with measured ash-free carbon values between 50 and $55 \%$. However, bound water probably represents a significant proportion of the measured dry weight in the four marine samples with the lowest carbon contents $(9-12$ in Table 1). Accounting for bound water may significantly alter calorific and carbon values. If it represents $8 \%$ of the dry weight (minus free water only) in Noctiluca (fed) the carbon figure increases from $40.4 \%$ to $51.7 \%$ of the ash-free dry weight (minus all water and ash). The corresponding increase in calorific value is from 18.0 to $23.1 \mathrm{~J} \mathrm{mg}^{-1}$. Evidence suggests (Paine, 1964; Mitchell \& Smith, 1977) that bound water is not 
Table 3. Calorific and carbon values in two hypothetical examples of the ciliate Tetrahymena estimated from proximate analysis. Samples $A$ und B represent low and high energy examples respectively. The ranges of percentage contribution from each macromolecule type were obtained from Elliott (1973). The results obtained by direct calorimetry in this study are included for comparison

\begin{tabular}{|lcccc|}
\hline \multicolumn{1}{|c|}{ Compounds } & A & B & Axenic & Fed on bacteria \\
\hline Lipid (\%) & 8 & 25 & & \\
Protein (\%) & 35 & 50 & & \\
Carbohydrate (\%) & 44 & 12 & & \\
Ash (\%) & 13 & 13 & 12.6 & 14.1 \\
$\mathrm{~J} \mathrm{mg}^{-1}$ (AFDW) & 21.9 & 27.4 & 24.0 & 24.8 \\
Carbon \% (AFDW) & 49.4 & 57.8 & 54.4 & 54.2 \\
\hline
\end{tabular}

Table 4. Ranges of possible bound water components in the oven-dried samples considered in this study (see text for details of calculation)

\begin{tabular}{|c|c|c|c|}
\hline \multirow[t]{2}{*}{ Species/sample } & \multirow{2}{*}{$\begin{array}{l}\text { Marine (M) or } \\
\text { freshwater (F) }\end{array}$} & \multicolumn{2}{|c|}{ Bound water $(\%)$} \\
\hline & & maximum & minimum \\
\hline Noctiluca - plankton & M & 18.9 & 13.3 \\
\hline Bacteria - marine & M & 19.8 & 11.8 \\
\hline Noctiluca miliaris - starved & M & 11.3 & 6.6 \\
\hline N. miliaris - fed & M & 13.8 & 3.7 \\
\hline Proteose peptone - yeast extract & - & 13.1 & -6.0 \\
\hline Euplotes sp. (algae) & M & 19.0 & -9.5 \\
\hline Euplotes sp. (bacteria) & M & 16.9 & -11.0 \\
\hline Dunaliella primolecta & $\mathrm{M}$ & 20.5 & -12.6 \\
\hline Eufolliculina sp. (bacteria) & M & 14.8 & -12.9 \\
\hline Paramecium caudatum & $F$ & 19.7 & -13.0 \\
\hline Plankton A & $F$ & 18.8 & -13.1 \\
\hline Bacteria - freshwater & $\mathrm{F}$ & 15.7 & -16.7 \\
\hline Tetrahymena pyriformis (bacteria) & $\mathrm{F}$ & 14.3 & -17.3 \\
\hline T. pyriformis (axenic) & $\mathrm{F}$ & 14.2 & -18.1 \\
\hline Ceratium hirundinella & F & 16.2 & -18.8 \\
\hline Eufolliculina sp. (algae) & $M$ & 11.0 & -20.6 \\
\hline Plankton B & $\mathrm{F}$ & 12.0 & -22.6 \\
\hline
\end{tabular}

removed at temperatures lower than $130-140^{\circ} \mathrm{C}$. It is widely believed (Lovegrove, 1966; Paine, 1971) that such elevated temperatures will also lead to volatilization of part of the organic weight. Thermogravimetric analysis might provide a direct and more precise measure of the bound water component.

However, the presence of bound water does not interfere in any obvious way with estimates of calorific value expressed per unit weight of carbon since it accounts for the same proportion of total weight in samples employed for both calorimetry and carbon analysis. Figures calculated for the expression $\mathrm{J}(\mathrm{mg} \mathrm{C})^{-1}$ lie within a narrow range (Table 2). These uncorrected figures lie close to the centre of the slightly wider range covering the principal components of the organic fraction (approximate figures are 41,45 
and $53 \mathrm{~J} \mathrm{(mg} \mathrm{C})^{-1}$ for carbohydrates, proteins and lipids respectively). The energy content per unit carbon in organisms will increase slightly as the carbon content increases (see Salonen et al., 1976). Incorporation of the data for Protozoa and marine plankton did not improve the significance of such a relationship described by these authors.

Bearing in mind the diversity of organisms and samples considered in this study and the relatively narrow range of values for energy per unit carbon, such figures might be accepted as conversion factors for aquatic organisms in general. Support for this acceptance is provided by the close agreement with empirical values obtained for the constituent organic compounds. Salonen et al. (1976) suggested conversion factors of $46 \mathrm{~J}$ (mg C) $)^{-1}$ and $41 \mathrm{~J}_{\mathrm{N}}(\mathrm{mg} \mathrm{C})^{-1}$ for aquatic invertebrates. The figures obtained from all

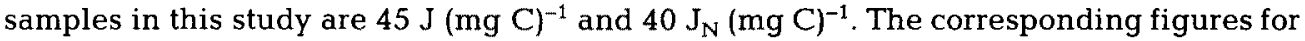

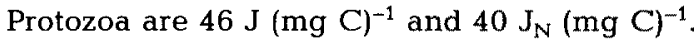

Acknowledgements. We are indebted to Dr. J. Hilton who performed most of the C and N analyses, and to Dr. J. Craig for useful discussions. We gratefully acknowledge the technical assistance of Mr. G. Sahling and Miss B. Paetow. Travelling funds were also provided for the first author by the Biologische Anstalt Helgoland.

\section{LITERATURE CITED}

Berk, S. G., Brownlee, D. C., Heinle, D. R., Kling, H. J. \& Colwell, R. R., 1977. Ciliates as a food source for marine planktonic copepods. - Microb. Ecol. 4, 27-40.

Craig, J. F., Kenley, M. J. \& Talling, J. F., 1978. Comparative estimations of the energy contents of fish tissue from bomb calorimetry, wet oxidation and proximate analysis. - Freshwat. Biol. 8 , $585-590$.

Cummins, K. C. \& Wuycheck, J. C., 1971. Calorific equivalents for investigations in ecological energetics. - Mitt. int. Ver. theor. angew, Limnol. 18, 1-158.

Curds, C. R, 1973. The role of protozoa in the activated-sludge process. - Am. Zool. 13, 161-169.

Curl, H., 1962. Analyses of carbon in marine plankton organisms. - J. mar. Res. 20, 181-188.

Elliot, A. M., 1973. Biology of Tetrahymena. Dowden, Hutchison \& Ross, Stroudsburg, Pa., 508 pp.

Elliot, J. M. \& Davison, W., 1975. Energy equivalents of oxygen consumption in animal energetics. Oecologia 19, 195-201.

Fenchel, T, 1967. The ecology of marine microbenthos 1,-Ophelia 4, 121-137.

Finlay, B. J., 1978. Community production and respiration by ciliated protozoa in the benthos of a small eutrophic loch. - Freshwat. Biol. 8, 327-341.

Goulder, R., 1971. The effects of saprobic conditions on some ciliated protozoa in the benthos and hypolimnion of a eutrophic pond. - Freshwat. Biol, 1, 307-318.

Heaney, S. I. \& Furnass, T. I., 1980. Laboratory models of diel vertical migration in the dinoflagellate Ceratium hirundinella. - Freshwat. Biol. 10, 163-170.

Kersting, K., 1973. A nitrogen correction for calorific values. - Limnol. Oceanogr. 17, 643-644.

Kitching, J. A., 1967. Contractile vacuoles, ionic regulation and excretion. In: Research in Protozoology. Ed. by T. T. Chen. Pergamon Press, London, 1, 307-336.

Kopylov, A. I., 1979. On the chemical composition and caloricity of Infusoria. - Okeanologija 19, 885-889.

Laybourn, J. E. M. \& Stewart, J. M., 1975. Studies on consumption and growth in the ciliate Colpidium campylum Stokes. - J. Anim. Ecol. 44, 265-174.

Lovegrove, T., 1966. The determination of the dry weight of plankton and the effect of various factors on the values obtained. In: Some contemporary studies in marine science. Ed. by H. Barnes. Allen \& Unwin, London, 429-467.

McLachlan, J., 1973. Growth media - marine. In: Handbook of phycological methods. Ed. by J. R. Stein. Univ. Press, Cambridge, 25-51. 
Mitchell, J. \& Smith, D. M., 1977. Aquametry. P. 1: A treatise on methods for the determination of water. Wiley, New York, 632 pp.

Oppenheimer, C. H. \& ZoBell, C. E., 1952. The growth and variability of sixty-three species of marine bacteria as influenced by hydrostatic pressure. - J. mar. Res. 11, 10-18.

Paine, R. T., 1964. Ash and calorie determinations of sponge and opitsthobranch tissues. - Ecology $45,384-387$.

Paine, R. T, 1971. The measurement and application of the calorie to ecological problems. $-A$. Rev. Ecol. Syst. 2, 145-164.

Platt, T. \& Irwin, B., 1973. Caloric content of phytoplankton. - Limnol. Oceanogr. 18, 306-310.

Porter, K. G., Pace, M. L. \& Battey, J. F., 1979. Ciliate protozoans as links in freshwater planktonic food chains. - Nature, Lond. 277, 563-565.

Prochazcha, G. J., Payne, W. J. \& Mayberry, W. R, 1973. Calorific contents of microorganisms. Biotechnol. Bioeng. 15, 1007-1010.

Rieper, M. \& Folotow, C., 1981. Feeding experiments with bacteria, ciliates and harpacticoid copepods. In: 15th European marine symposium. (In press).

Rogerson, A., 1979. Energy content of Amoeba proteus and Tetrahymena pyriformis (Protozoa). Can. J. Zool. 57, 2463-2465.

Salonen, K., Sarvala, J., Hakala, I. \& Viljanen, M. L., 1976. The relation of energy to organic carbon in aquatic invertebrates. - Limnol. Oceanogr. 21, 724-730.

Slobodkin, L. B. \& Richman, S., 1961. Calories/gm in species of animals. - Nature, Lond. 191, 299.

Uhlig, G., 1965. Die mehrgliedrige Kultur litoraler Folliculiniden. - Helgoländer wiss. Meeresunters, $12,52-60$.

Uhlig, G. 1972. Entwicklung von Noctiluca miliaris. Publ. Wiss. Film (Sect. Biol.) 5, 400-411.

Uhlig, G., 1981. Microfaunal food organisms for mariculture. - Aquaculture. (In press).

Winberg, G. G. (Ed.), 1971. Symbols, units and conversion factors in studies of freshwater productivity. I. B. P. (Sect. PF), London, 23 pp.

Winberg, G. G. \& Duncan, A. (Eds), 1971. Methods for the estimation of production of aquatic animals. Acad. Press, London, 175 pp. 